«The Great Commoner» for Winston Churchill

«The Great Emancipator» for Abraham Lincoln

«The Great Silent One» for Helmuth von Moltke the Elder

«The Greatest» for Muhammad Ali

«The Iron Chancellor» for Otto von Bismarck

«The Iron Lady» or «The Leaderene» for Margaret Thatcher

«The Queen of Pop» or «The Material Girl» for Madonna

PLACES:

«Auld Reekie» for Edinburgh

«City of Dreams» for Mumbai

«The Big Apple» for New York City

«The City of Light» for Paris

«The Eternal City» or «Urbe» for Rome

«The Smoke» for London

«The Windy City» for Chicago

So, we can say that antonomasia as special stylistic device of nominating a person always creates significant pragmatic effect. In given examples predominates the use of common names instead of proper ones that has a characterizing function. Often it is positive characterization of a person or place.

Perspectives of further research involves studying of the pragmatic effect of antonomasia, as well as other stylistic devices, on the base of work of fiction. In particular, it is interesting to see which stylistic devices promotes deviation from the maxim of quality and systematize these devices from the point of view of pragmatics.

\title{
References
}

1. Efimov L. P. (2004), Stylistics of English language and discursive analysis. Educational methodical manual, Vinnytsia: «New Book», 240 s.

2. Stylistic devices dictionary [E-resource], Available at: http://estylistics.blogspot.com/2012/05/antonomasia-can-be-in-way-variety-of.html, [Accessed 12 February 2018].

3. Yemets O. V. (2012), Investigating of pragmatic effect of antonomasia. Saarbrucken: LAP Lambert Academic Publishers, 69 s.

4. Arnold I. V. (2004), Stylistics. The Modern English Language. M. : Flinta, Nauka, 384 s.

5. Figures of speech. Antonomasia examples [E-resource], Available at: http://fos.iloveindia.com/antonomasia-examples.html, [Accessed 12 February 2018].

\section{УДК 159.923:378.011.3-052}

\section{СПЕЦИФІКА ПРОФЕСІЙНОЇ ІДЕНТИФІКАЦЇ̈ СУЧАСНИХ СТУДЕНТІВ} Гошовська Д.Т.

\section{SPECIFICITY OF PROFESSIONAL IDENTIFICATION OF MODERN STUDENTS} Hoshovska Daria

У статті йдеться про психологічні особливості професійної ідентифікації сучасних студентів. Встановлено, щзо набуття особистісної ідентичності висувається в ранг базових, фундаментальних потреб людини, адже засвідчує ї̈ спроможність до віднайдення власної тотожної самості як у площинах індивідуального буття, так і в просторі фахової 
самореалізації. Наголомено, щзо ненабуття конструктів фахового самоусвідомлення та ідентичності або нехтування ними, проявляється в індивідуальних і соціальнних вимірах, насамперед у розладах ідентифікації, аморфності самовизначення та розбалансуванні багатьох інших параметрів особистісної психоструктури.

Ключові слова: студенти, ототожнення, ідентифікація, професійна ідентичність.

The article deals with the psychological peculiarities of the professional identification of modern students. It has been established that the acquisition of personal identity is being promoted to the rank of basic and fundamental human needs, because it shows its ability to find its own identical identity both in the planes of individual being and in the sphere of professional selfrealization. The non-intentionality of constructs of professional self-awareness and identity or neglect of them, manifests itself in individual and social dimensions, first of all in identification disorders, amorphism of self-determination and disbalancing of many other parameters of personal psychostructure have been emphasized. It is noted, that important key to acquire the professional identity, is use of the principle of integrity in the light of the studying the widest network of communicative and perceptual relations of student, finding the main triggers and barriers of communication in these relationships, separating the factors of most significant influence on the formation of its integration / disintegration. The importance of professional psychological support of the complex process of self-organization as inclination, intention and desire of student to identification changes, is revealed.

Keywords: students, identification, identity, professional identification.

Ідентичність $є$ однією 3 найважливіших i найнеобхідніших умов повноцінного розвитку особистості, iï творчої спрямованості й продуктивності у всіх векторах самоактуалізації: від інтимно-індивідуальних до соціально-професійних. Набуття адекватної особистісної ідентичності висувається в ранг базових, фундаментальних потреб людини, адже засвідчує іiі спроможність до віднайдення власної тотожної самості як у площинах індивідуального буття, так і в просторі фахової самореалізації. Унікальність і значущість поняття «ідентичність» як форми набуття людиною самобутності, своєрідної рефлексії 3 приводу становлення iї як особистості добре означена А. Тоффлєром, який писав, що

«мільйони індивідів напружено шукають свою власну ідентичність чи деяку магічну терапію, що полегшує набути цілісність особистості, щоб перемогти хаос, внутрішню ентропію, сформувати власний порядок» [3, 123]. Отож оволодіння ідентичністю як своєрідною ментальною самототожністю є актуальною онто- і соціогенетичною домінантою та може виявлятися в осіб різного віку, статі, соціального статусу, професійного й екзистенційного досвіду.

Мета і завдання статті - окреслення психологічних особливостей розвитку фахової ідентичності в сучасних студентів.

Істотної значущості набувають дослідження професійної ідентичності у студентської молоді, зокрема упродовж складного й насиченого процесу іiі професійного навчання, оскільки невирішеність цієї нагальної проблеми, тобто не набуття конструктів фахового самоусвідомлення та ідентичності чи нехтування ними, проявляється в індивідуальних i соціальних вимірах, насамперед у розладах ідентифікації, аморфності самовизначення та розбалансуванні багатьох інших параметрів особистісної психоструктури. В юності, на студентському етапі соціалізації не менш нагальною постає проблема кризи ідентичності, коли відбуваються дуже складні процеси фахової професіоналізації, соціальної адаптації, особистісної самореалізації тощо. Формування впевнених просоціальних перспективних життєвих ліній, побудова власної моделі професійного самоздійснення можливі лише на базі сформованості в молодої людини потужного «балансу ідентичності» як об’єктивного й оптимістичного ракурсу світобачення $[1 ; 2 ; 3]$. 
Професійно-рольова ідентифікація студента, що розглядається як один із найважливіших механізмів його соціалізації, розпочинається ще у школі, переростаючи згодом у реалії студентського життя. Вона пов'язана, насамперед із прийняттям студентом нової соціально-рольової позиції майбутнього спеціаліста, формування соціальнопрофесійного аспекту його Я-концепції, інтеріоризацією гуманістичних цінностей, виробленням відповідних професійних настановлень тощо. Вся навчально-виховна робота зі студентами 3 використанням генетичного підходу повинна базуватися на врахуванні та виконанні основних, засадничих положень, які лежать в основі самоорганізації систем. Сучасний студент у трансформаційних умовах дійсності (соціально-економічна нестабільність, політично-ідеологічні парадокси, модернізаційні освітні процеси тощо), розглядається нами як особистість, що знаходиться у пункті біфуркації та $є$ досить часто дисбалансованою через вплив зовнішніх i/або внутрішніх чинників.

Оскільки основними процесами у складному функціонуванні соціально-психічної реальності людини є процеси організації/самоорганізації як утворення нових структур, то ідентифікація має базуватися на врахуванні таких закономірностей, що підвищення цілісності і внутрішньої несуперечності $€$ прогресивним вектором, а збільшення роздробленості і конфліктності $\epsilon$ регресивним гальмівним напрямком. Ідентифікація передбачає поступове підвищення організованої складності, збільшення кількості взаємопов'язаних рівнів і гнучкість соціально-психологічної реальності студента як саморефлексуючої цілісної системи. Завдяки цьому процес ідентифікації набуває ознак цілісної самоорганізованої системної діяльності, в якій психіка студента, переживаючи внутрішні трансформації, перероджується в якісно нові інваріанти й розвивається у напрямку набуття особистісної та соціальної, зокрема й професійної ідентичності. Важливою запорукою набуття фахової ідентичності $€$ застосування принципу цілісності в ракурсі вивчення найширшої мережі комунікативно-перцептивних зв'язків студента, знаходження основних трігерів і бар'єрів спілкування в цих взаєминах, виділення чинників, що найвагоміше впливають на формування інтеграції/дезінтеграції, розгляд їх якіснофункціональних властивостей на основних рівнях особистісної самопрезентації (Яіндивідуальне/групове, Я-реальне/ідеальне, Я-статичне/потенційне, Япрезентоване/масковане та ін.). Проблема формування ідентифікаційної структури як об'єкта складної природи повинна розглядатися через виконання завдань іï раціоналізації, грунтованої на методах проектування 3 урахуванням соціально-психологічної та індивідуально-психологічної специфіки студентів. Функціональні системно-цільові основи ідентифікації повинні бути гнучкими, включати в себе достатньо широкий спектр методів, алгоритмів і програм для того, щоб забезпечити можливість вибору найадекватнішої моделі та найефективніших методів і алгоритмів у кожній конкретній ситуації. Дуже часто психологічною основою кризи ідентичності у студентів $€$ порівняння ідеального Я 3 реальним Я. Однак ідеальне Я може бути ще випадковим, а реальне Я ще повністю не оцінене особистістю, тому єдиним засобом зняття цієї суперечності повинна стати індивідуальна творчо-перетворювальна діяльність, упродовж якої студент змінює як самого себе, так і реалії навколишнього освітнього простору. Міра його індивідуалізації починається iз соціального і професійного самовизначення, а повинна завершитися набуттям зрілої фахової ідентичності.

Ми виходимо з усталених позицій, що поняття «ідентифікація» доцільно тлумачити як видове й похідне від базового терміну «ідентичність», тобто насамперед у діяльніснофункціональному сенсі, як складний i розгалужений механізм набуття особистістю тотожності, зокрема й професійної. Ідентифікація потребує виділення системотвірних зв'язків, що надають їй як системі певну логічну послідовність і впорядкованість, а також аналізу структурних елементів актуальної ситуації розвитку та реальних умов і можливостей управління, регулювання, цілеспрямованою діяльністю на позитивний еволюційний шлях набуття професійної ідентичності. Тому одним з основних «ідентифікаційних завдань» $\epsilon$ 
розкриття мережі сутнісних ознак, глибинних зв'язків і субстанційних властивостей соціопсихоструктури особистості студента з метою віднайдення адекватних способів набуття ним фахової ідентичності.

Отож професійна ідентичність - це продуктивна динамічна система, яка формується упродовж багатоланкової професійної освіти, сприяє набуттю інтелектуально-ціннісного тезаурусу знань, умінь і навичок для активного й плідного розвитку фахової компетентності та самореалізації. Особистісне й фахове вдосконалення 3 метою набуття конструктів ідентичності на рівні психолого-педагогічної майстерності є запорукою успішної діяльності майбутнього спеціаліста в кожній галузі. Професійна ідентичність є свідченням (і дієвим засобом формування) збалансованої Я-концепції, яка на особистісному рівні відображає власні індивідуальні характерологічні риси, цінності, емоції та інші «елементи» психоструктури, а на соціально-психологічному рівні характеризує уявлення про себе у системі міжособистісних взаємин, що відображає статусно-рольове членство у різноманітних соціальних професійних групах. Оптимізація особистісного потенціалу студента у визначенні самоідентичності дозволить йому впевнено справитися з проблемами навчальновиховного процесу в університеті, переживаннями упродовж індивідуального розвитку й соціального становлення i, загалом, у формуванні всієї життєвої стратегії. Перспективи наших подальших досліджень зводяться до розширення моніториногового вивчення окресленої проблематики в різновіковому та інтердисциплінарному порівняльному ключі.

\section{Список використаних джерел}

1. Гошовська Д. Індивідуальні характеристики професійної ідентичності: постановка проблеми / Д. Гошовська / Збірник матеріалів наукової конференції / за ред. проф. М.В. Савчина. - Дрогобич, 2010. - Вип.4. - С.25-33.

2. Игнатенко П.И. Идентичность: философский и психологический анализ/ П. И. Игнатенко, Н. В. Павленко. - К.: Арт-прес, 1999. - 466с

3. Toffler A. The Third Wave. - N. Y. ,1980. - 366 s.

\section{References}

1. Goshovska D. (2010), Indyvidualni kharakterystyky profesiinoi identychnosti: postanovka problem [Individual characteristics of professional identity: problem setting], Collection of materials of the scientific conference, by ed. prof. M.V. Savchina, Drohobych, Vol.4., pp. 25-33.

2. Ignatenko P.I., Pavlenko N.V. (1999), Ydentychnost: fylosofskyi y psykholohycheskyi analyz [Identity: philosophical and psychological analysis], K .: Art-press, 466 p.

3. Toffler A. The Third Wave. - N. Y., 1980. - 366 p.

\section{УДК 376.042.011.3-052}

\section{ОЦІНКА АДАПТАЦЇ̈ ОСВІТНЬОГО ПРОЦЕСУ ДО ПОТРЕБ УЧНІВ 3 ОБМЕЖЕНИМИ МОЖЛИВОСТЯМИ ЗДОРОВ'Я}

Іванашко О.С., Вічалковська Н.К.

\section{ASSESSMENT OF EDUCATIONAL ADAPTATION TO THE NEEDS OF ENHANCERS WITH RESTRICTED HEALTH CHALLENGES}

Ivanashko Oksana, Vichalkovska Natalia

У статті висвітлено адаптаційні можливості освітнього прочесу $y$
загальноосвітньому навчальному закладі до потреб учнів з особливими освітніми 